\title{
Korelasi Ekspresi Protein Deleted in Colorectal Cancer (DCC) dengan Keganasan Kolorektal Stadium II dan III
}

\author{
Ida Bagus Budhi Surya Adnyana, Reno Rudiman \\ Bagian Bedah \\ Fakultas Kedokteran Universitas Padjadjaran \\ Rumah Sakit Hasan Sadikin, Bandung
}

\begin{abstract}
Abstrak
Gen deleted in colorectal cancer (DCC) merupakan salah satu gen supresor tumor yang memegang peranan untuk terjadinya keganasan kolorektal. Mutasi gen DCC didapatkan pada 70\% kasus dan tidak adanya ekspresi protein DCC ini memberikan prognosis buruk pada kasus keganasan kolorektal. Tujuan penelitian ini adalah untuk mengetahui apakah ekspresi protein DCC berhubungan dengan kemungkinan metastasis keganasan kolorektal. Penelitian ini merupakan penelitian cross-sectional, data diambil secara retrospektif. Data didapatkan dari sediaan blok parafin di Bagian Patologi Anatomi RS Hasan Sadikin Bandung periode bulan Mei sampai Agustus 2007. Dari 38 sampel, terdiri dari 19 sampel untuk stadium II dan 19 sampel stadium III, kemudian dilakukan pemeriksaan imunohistokimia. Hasil penelitian menunjukkan, usia termuda 18 tahun dan tertua 83 tahun. Berdasarkan jenis kelamin terdapat 18 sampel $(47,4 \%)$ pria dan 20 sampel $(52,6 \%)$ wanita. Sampel dengan stadium II memberikan ekspresi protein DCC, sedangkan pada stadium III, didapatkan 5 sampel $(13,16 \%)$ yang tidak memberikan ekspresi DCC. Dari uji statistik didapatkan nilai chi kuadrat sebesar 5,758 dengan $p=0,016(p<0,05)$. Dapat disimpulkan bahwa terdapat hubungan yang bermakna antara stadium keganasan kolorektal dan ekspresi protein DCC.
\end{abstract}

[MKB. 2010;42(1):12-6].

Kata kunci: Stadium keganasan kolorektal, mutasi, ekspresi DCC

\section{Correlation Between Deleted in Colorectal Cancer (DCC) Protein Expression and Stage II - III of Colorectal Cancer}

\begin{abstract}
Deleted in colorectal cancer (DCC) gene is one of the tumor supressor genes which play a role in colorectal pathogenesis. Mutation of this DCC gene was found in approximately $70 \%$ cases and the absence of DCC protein expression give the poor prognosis. The aim of the study was to evaluate whether the expression of DCC protein had a correlation with metastasis probability of the stage II and III colorectal cancer. This was a cross-sectional study and data were obtained retrospectively. The data consisted of 38 colorectal carcinoma samples in second and third stadium, 19 samples in each stadium, during the period of May to August 2007. We perfomed imunohistochemistry examination. On this study, the youngest was 18 years old and the oldest was 83 years old. According to gender, 18 samples $(47.4 \%)$ were male and 20 samples $(52.6 \%)$ were female. All samples in stage II stadium gave expression of the DCC protein and there were 5 samples $(13.16 \%)$ with stadium III didn't give expression. From statistical analysis, chi square 5.758 and the $p$-value was $0.016(\mathrm{p}<0.05)$. We can conclude that there is a correlation between the colorectal carcinoma stadium and the expression of DCC protein. [MKB. 2010;42(1):12-6].
\end{abstract}

Key words: Colorectal cancer stage, mutation, DCC expression

Korespondensi: dr. Ida Bagus Budhi Surya Adnyana, Sp.B, Bagian Bedah, Fakultas Kedokteran Universitas Padjadjaran, Rumah Sakit Hasan Sadikin, Bandung, Tlp. (022) 2034574, Email: budhi_suryaadnyana@yahoo.com 


\section{Pendahuluan}

Karsinoma kolorektal merupakan keganasan pada saluran cerna yang paling sering didapatkan. Di Amerika Serikat, ditemukan lebih dari 145.000 kasus baru sudah terdiagnosis dan 55.000 pasien meninggal setiap tahunnya. Karsinoma kolorektal merupakan penyebab kematian urutan kedua di Amerika Serikat. Perbandingan antara laki-laki dan perempuan kurang lebih sama, serta insidensinya tidak berubah dalam waktu 20 tahun terakhir.' Estimasi WHO menyatakan kurang lebih didapatkan 945.000 kasus baru per tahunnya dilaporkan di seluruh dunia dengan 492.000 kematian setiap tahunnya. ${ }^{2}$

Di Indonesia, dilaporkan adanya karsinoma kolorektal sebanyak 1,8 per 100.000 penduduk, berdasarkan laporan WHO tahun 2002, insidensi AKK (adenokarsinoma kolorektal) di Indonesia sebesar 17,8 per 100.000 penduduk. Rasio antara penderita laki-laki dan wanita adalah $1: 1,2$.

Sebagian besar dari penderita karsinoma kolorektal datang ke rumah sakit sudah dalam keadaan stadium lanjut. Dalam penanganan bedah kasus karsinoma kolorektal, untuk mengetahui stadium kasus tersebut, serta selain dilakukan pemeriksaan patologi anatomi pada sediaan massa tumor, perlu juga dilakukan pemeriksaan pada temuan kelenjar getah bening yang ada, di sini diperlukan akurasi pemeriksaan patologi yang baik. Pada saat ini telah berkembang pemeriksaan imunohistokimia pad kasus karsinoma kolorektal, pemeriksaan ini sangat penting untuk mengetahui sifat tumor primer tersebut (kecenderungan untuk bermetastasis). ${ }^{3,4}$

Karsinoma kolorektal merupakan suatu kasus kelainan genetik, didapatkan perubahan genetik dan laju pertumbuhan sel yang progresif. Secara garis besar, gen yang berperan untuk terjadinya karsinoma kolorektal dikelompokkan menjadi tiga, antara lain onkogen (K-ras), tumor supresor gen (APC, -p53, DCC), dan mismatch repair gen (Hmsh2, Hmlh1, Hpms1, Hpms2)., ${ }^{1,58}$

Adanya mutasi dari gen-gen tersebut dapat mengakibatkan keganasan kolorektal. Pada tahun 1990, Fearon dan Vogelstein, seperti dikutip oleh Kelli, ${ }^{1}$ memperkenalkan patogenesis terjadinya karsinoma kolorektal, dikatakan paling tidak ditemukan adanya 5 mutasi gen.

Angka harapan hidup (survival rate) penderita karsinoma kolorektal ditentukan oleh stadium keganasan, pada kasus stadium lanjut, angka harapan hidup penderita akan semakin rendah.,11 Pada karsinoma kolorektal stadium II, angka harapan hidup 5 tahun kurang lebih 54-65\%, sedangkan pada stadium III lebih rendah, sebesar $39-60 \%$.

Adanya mutasi gen seperti gen DCC (deleted in colorectal cancer) memegang peranan dalam menentukan prognosis dari penderita dengan keganasan kolorektal. ${ }^{11,12}$ Mutasi dari gen DCC didapatkan pada $70 \%$ kasus serta tidak adanya protein DCC ini memberikan prognosis yang buruk pada kasus keganasan kolorektal. ${ }^{13,14}$

Tujuan penelitian ini adalah untuk mengetahui apakah ekspresi protein DCC oleh sel tumor berhubungan dengan kemungkinan metastasis keganasan kolorektal stadium II dan III.

Dengan makin meningkatnya angka kejadian keganasan kolorektal dan makin berkembangnya pemeriksaan imunohistokimia untuk menilai sifat biologis tumor primer keganasan tersebut, kita akan melihat ekspresi protein gen DCC pada ke-2 stadium keganasan kolorektal tersebut.

\section{Metode}

Penelitian ini merupakan suatu penelitian cross sectional, data diambil secara retrospektif. Bahan pemeriksaan yang digunakan adalah 38 sediaan blok parafin dari pasien dengan adenokarsinoma kolorektal, dikumpulkan dari Mei sampai Agustus 2007 dan dikirim ke Bagian Patologi Anatomi RS. Hasan Sadikin Bandung. Dilakukan pemeriksaan imunohistokima pada sediaan blok parafin yang telah ada.

Pemeriksaan imunohistokimia dilakukan untuk melihat ada tidaknya ekspresi protein DCC pada sediaan blok parafin dengan pewarnaan menggunakan antibodi DCC. ${ }^{14}$ Teknik yang digunakan adalah prosedur streptavidin-biotin, yang terdiri dari lima tahap.

Pada tahap I, dilakukan pencucian sediaan parafin blok dengan menggunakan larutan xilen, alkohol absolut, alkohol 95\% selama 5 menit, dan dilakukan 2 kali pencucian. Berikutnya, tahap II dipergunakan larutan metanol kemudian dibilas dengan air suling dan larutan bufer selama 10 menit untuk menghilangkan aktivitas peroksidase endogen. Sesudah itu diberikan antigen pada tahap III dan dibilas larutan bufer selama 10 menit. Setelah diberikan antigen, pada tahap IV perlu dihilangkan pewarnaan dasar nonspesifik 
mempergunakan blocking solution dan larutan bufer selama 10 menit. Tahap terakhir, dilakukan pewarnaan imunohistokimia dengan pemberian antibodi primer yang bervariasi.

Ekspresi protein DCC dinilai positif apabila distribusi intensitas pewarnaan imunoreaktif yang diberikan dapat bermanifestasi pada membran dan sitoplasma. Pemeriksaan dengan menggunakan mikroskop cahaya pembesaran 100x.

\section{Hasil}

Pemeriksaan imunohistokimia dinilai dari ada atau tidaknya ekspresi protein DCC pada kedua stadium tersebut, serta dari karakteristik subjek berdasarkan usia dan jenis kelamin. Sesuai dengan penentuan ukuran sampel, diperiksa sediaan blok parafin dari 38 subjek penelitian. Berdasarkan hasil penelitian, dari keseluruhan subjek yang diamati usia termuda 18 tahun dan usia tertua 83 tahun. Dari 38 sampel penelitian, didapatkan 19 sampel dengan stadium II dan III, usia termuda 18 tahun untuk stadium II dan 19 tahun untuk stadium III. Sedangkan usia tertua berturut-turut 77 tahun dan 83 tahun. Setelah dilakukan pemeriksaan imunohistokimia DCC dan dihubungkan dengan usia, pada sampel yang memberikan ekspresi DCC, usia termuda adalah 18 tahun sedangkan usia tertua 77 tahun. Pada sampel penelitian yang tidak memberikan ekspresi DCC, usia termuda dan tertua berturut-turut adalah 26 tahun dan 83 tahun.

Dari semua sampel ternyata stadium II yang

Tabel 1 Deskripsi Statistik Usia Subjek Berdasarkan Jenis Kelamin, Stadium, dan Imunohistokimia DCC

\begin{tabular}{llccccccc}
\hline \multicolumn{1}{c}{ Karakteristik } & Kel & Min & Mak & Med & K1 & K3 & Rata & SD \\
\hline Jenis kelamin & Pria & 18 & 83 & 49 & 38 & 59 & 48,17 & 16,48 \\
& Wanita & 19 & 78 & 45 & 33 & 67 & 49,25 & 18,91 \\
Stadium & II & 18 & 77 & 49 & 39 & 60 & 48,32 & 16,42 \\
& III & 19 & 83 & 46 & 32 & 64 & 49,16 & 19,09 \\
Imunohistokimia & Positif & 18 & 77 & 48 & 35 & 60 & 47,42 & 16,41 \\
DCC & Negatif & 26 & 83 & 60 & 33 & 80 & 57,40 & 24,40 \\
\hline
\end{tabular}

Tabel 2 Tabulasi Silang Antara Stadium dan Imunohistokimia DCC

\begin{tabular}{|c|c|c|c|c|c|c|}
\hline \multirow{3}{*}{ Stadium } & \multicolumn{4}{|c|}{ Imunohistokimia DCC } & \multirow{2}{*}{\multicolumn{2}{|c|}{ Total }} \\
\hline & \multicolumn{2}{|c|}{ Positif } & \multicolumn{2}{|c|}{ Negatif } & & \\
\hline & $\mathbf{n}$ & $\%$ & $\mathbf{n}$ & $\%$ & $\mathbf{n}$ & $\%$ \\
\hline II & 19 & 50,0 & 0 & 0 & 19 & 50,0 \\
\hline III & 14 & 36,8 & 5 & 13,2 & 19 & 50,0 \\
\hline Total & 33 & 86,8 & 5 & 13,2 & 38 & 100,0 \\
\hline
\end{tabular}

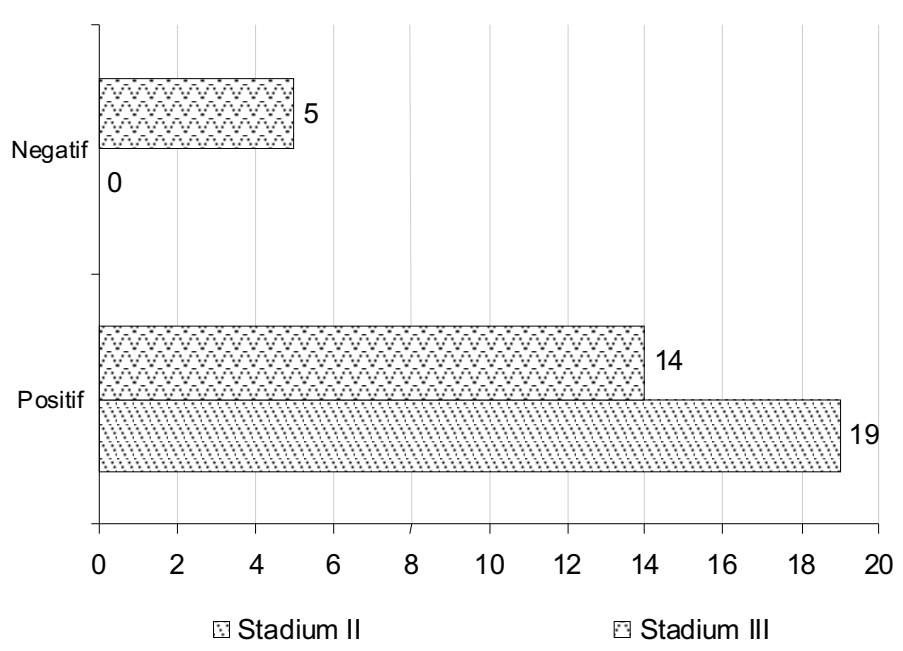

Gambar 1 Grafik Hasil Pemeriksaan Imunohistokimia dan Stadium 


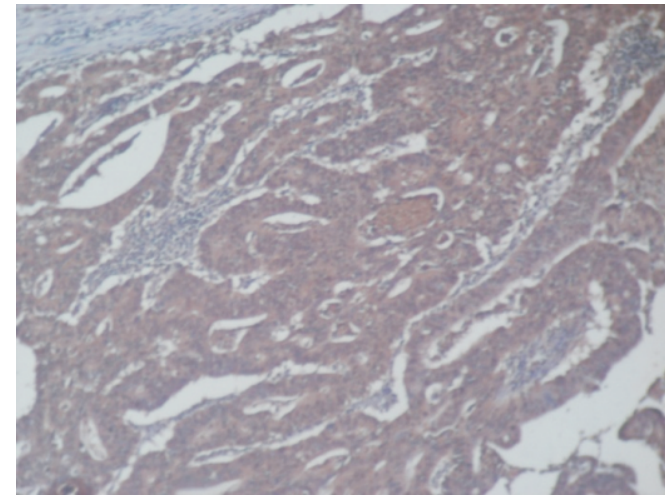

Gambar 2 Ekspresi Protein DCC (+)

memberikan ekspresi DCC, sedangkan pada sampel stadium III didapatkan lima sampel yang tidak memberikan ekspresi DCC.

Berdasarkan tabulasi silang antara stadium dan imunohistokimia, jika digambarkan kedalam bentuk grafik terlihat pada Gambar 1.

\section{Pembahasan}

Berdasarkan deskripsi di atas dan dihubungkan dengan kepustakaan yang ada, memang tidak ada yang menyatakan adanya pengaruh usia terhadap stadium keganasan kolorektal maupun dengan kemungkinan suatu keganasan tersebut akan memberikan ekspresi protein DCC atau tidak. ${ }^{1,-68}$

Bila melihat karakteristik sampel penelitian berdasarkan jenis kelamin yang dihubungkan dengan stadium keganasan kolorektal, pada stadium II didapatkan 12 subjek dengan jenis kelamin pria dan tujuh subjek wanita, sedangkan pada stadium III terdiri dari enam subjek pria dan 13 subjek wanita. Setelah analisis statistik, maka didapatkan nilai $p=0,051$. Hal ini berarti kedua hal tersebut tidak terdapat hubungan yang bermakna secara statistik. Berdasarkan kepustakaan hanya dijelaskan mengenai usia yang paling banyak mempunyai risiko keganasan kolorektal, yaitu usia di atas 40 tahun. Tidak ada yang menjelaskan adanya hubungan antara jenis kelamin dan stadium keganasan kolorektal. ${ }^{1,5,7}$

Dari pemeriksaan imunohistokimia DCC, pada subjek dengan jenis kelamin pria, terdapat 16 di antaranya memberikan ekspresi protein DCC dan pada jenis kelamin wanita, ekspresi DCC didapatkan pada 17 subjek. Penghitungan statistik yang dilakukan memberikan nilai $\mathrm{p}=0,128$. Hal ini

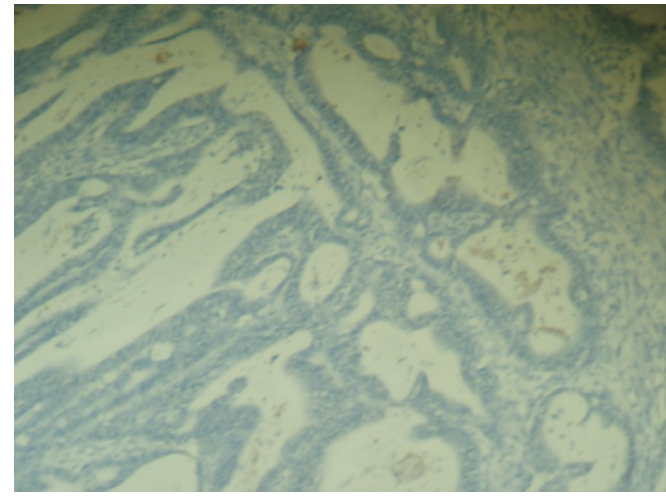

Gambar 3 Ekspresi Protein DCC (-)

berarti tidak ada hubungan yang bermakna secara statistik antara jenis kelamin dan protein DCC. Seperti yang telah dijelaskan di atas, pada keganasan kolorektal, jenis kelamin tidak mempunyai pengaruh terhadap stadium maupun ekspresi protein DCC. Ekspresi protein DCC ini berhubungan dengan prognosis dari keganasan kolorektal dan kemungkinan akan terjadinya metastasis karena fungsi protein DCC tersebut dalam hal adhesi antar sel, serta mencegah pertumbuhan, invasi, dan metastasis tumor. ${ }^{8}$

Hasil penelitian menunjukkan bahwa ekspresi protein DCC didapatkan pada seluruh sampel stadium II, sedangkan pada stadium III terdapat 5 sampel yang tidak memberikan ekspresi protein DCC. Secara statistik didapatkan hubungan yang bermakna antara stadium keganasan kolorektal dan ekspresi protein DCC. Hal ini berarti pada stadium kolorektal yang lebih awal (stadium II), lebih besar mempunyai kemungkinan masih didapatkannya ekspresi protein DCC. Hasil penelitian ini sesuai dengan kepustakaan yang menyatakan bahwa tidak adanya ekspresi protein DCC ini berhubungan dengan prognosis yang lebih buruk dan metastasis keganasan kolorektal. Penelitian lain yang dilakukan oleh Shibata, seperti dikutip James, ${ }^{8}$ pada stadium II, ditemukan juga beberapa sampel yang tidak memberikan ekspresi protein DCC dan setelah dibandingkan dengan stadium yang sama dan yang memberikan ekspresi protein DCC, sampel yang tidak didapatkan ekspresi protein DCC mempunyai angka harapan hidup 5 tahun lebih rendah. Hal tersebut memberikan pertimbangan untuk memberikan kemoterapi adjuvan pada kasus keganasan kolorektal stadium II yang tidak didapatkan ekspresi protein DCC.

Dari hasil penelitian ini dapat disimpulkan bahwa terdapat hubungan antara stadium tumor 
kolorektal dan ekspresi protein DCC. Stadium keganasan kolorektal yang terjadi lebih awal, kemungkinan didapatkan ekspresi protein DCC lebih besar dibandingkan dengan stadium lanjut. Hal ini mungkin dapat digunakan sebagai bahan pertimbangan untuk dilakukan pemeriksaan imunohistokimia pada kasus dengan keganasan kolorektal.

\section{Daftar Pustaka}

1. Kelli BM. Colon, rectum and anus. Dalam: Brunicardi FC, Anderson D, Dunn DL, penyunting. Schwartz's principles of surgery. Edisi ke-8. New York: McGraw-Hill Medical Publising: 2005. hlm. 1055-110.

2. WHO, IARC. Colorectal cancer in Southern Asia (diunduh 24 Januari 2005). Tersedia dari: www. depdb.iarc.fr/globocan2002.htm

3. Chen H. Principles of tumor biology. Dalam: Argenta LC, penyunting. Basic science for surgeon a review. Philadelphia: Saunders; 2004. hlm. 613-20.

4. Macdonald F, Ford CHJ, Casson AG. Moleculare biology of cancer. New York: Bios Scientific Publishers; 2004. hlm. 115-25.

5. Mark WL. Colorectal polyps and cancer. Dalam: Norton JA, Chang AE, Lowry SF, Pass HI, penyunting. Basic science and clinical evidence. New York: Springer Inc; 2003. hlm. 281-320.

6. George CJ. Cancer of large intestine. Dalam: Way
LW, Doherty GM, penyunting. Current surgical diagnosis and treatment. Edisi ke-11. Boston: McGraw-Hill Companies Inc; 2003. hlm. 716-24.

7. Debas HT. Gastrointestinal surgery: pathophysiology and management. New York: SpringerVerlag Inc; 2004.

8. James CM. Moleculare genetics of colorectal neoplasia. Dalam: Casey G, penyunting. Moleculare genetics and colorectal neoplasia, a primer for the clinician. Edisi ke-2. North America: Kluwer Academic Publisher; 2004. hlm. 69-87.

9. Carlo A, Domizia D, Lonardi S, Bandelloni R, Stefania C, Gallo L, dkk. Deleted in colorectal cancer protein expression in colorectal cancer metastasis. J Clin Oncol. 2004;22:3758-65.

10. Jen J, Kim H, Piantadosi S, Liu ZF, Lewitt RC, Pertti S, dkk. Allelic loss of chromosome 18q and prognosis in colorectal cancer. NEJM. 2004;31: 213-21 (diunduh 21 Oktober 2007). Tersedia dari: www.nejm.org

11. Mehlen P, Fearon ER. Role of dependence receptor DCC in colorectal cancer pathogenesis. J Clin Oncol. 2004;22:3420-8.

12. Chapelle A. Microsatellite instability. NEJM. 2003;349:209-10 (diunduh 21 Oktober 2007). Tersedia dari: www.nejm.org

13. Birbeck FK. Pathology and staging of rectal cancer. Dalam: Audisio RA, Gerghty JG, Longo WE, penyunting. Modern management of cancer of the rectum. London: Springer-Verlag Limited; 2001. hlm. 7-14.

14. Santa Cruz Biotechnology. Deleted in colorectal cancer (diunduh 11 Januari 2007). Tersedia dari: http://www.scbt.com. 